\title{
Major publications by Eva Gore-Booth
}

\section{Poetry}

Poems, London: Longmans Green \& Co, 1898.

The One and the Many, London: Longmans Green \& Co, 1904.

New Songs: A Lyric Selection made by AE from poems by Eva Gore-Booth and others. Dublin: O'Donoghue \& Co, 1904.

The Egyptian Pillar, Tower Press Booklets, Series 2, No. 3, Dublin: Maunsel, 1907.

The Agate Lamp, London: Longmans Green \& Co, 1912.

The Perilous Light, London: Erskine MacDonald, 1915.

Broken Glory, Dublin: Maunsel, 1917.

The Shepherd of Eternity, London: Longmans Green \& Co, 1925.

The House of Three Windows, London: Longmans Green \& Co, 1926.

Poems of Eva Gore-Booth: Complete Edition, Esther Roper (ed.), London: Longmans Green \& Co, 1929.

\section{Plays}

Unseen Kings, London: Longmans Green \& Co, 1904.

The Three Resurrections and the Triumph of Maeve, London: Longmans

Green \& Co, 1905.

The Sorrowful Princess, London: Longmans Green \& Co, 1907.

The Death of Fionavar from the Triumph of Maeve, London: Erskine

Macdonald, 1916.

The Sword of Justice, London: Longmans Green \& Co, 1918.

The Buried Life of Deirdre, London: Longmans Green \& Co, 1930.

The Plays of Eva Gore-Booth, Frederick S. Lapisardi (ed.), California: 
Mellen Research University Press, 1991.

Fiametta: A Previously Unpublished Play by Eva Gore-Booth, Sonja Tiernan (ed.), New York: Edwin Mellen Press, 2010.

\section{Prose}

A Psychological and Poetic Approach to the Study of Christ in the Fourth Gospel, London: Longmans Green \& Co, 1923.

The Inner Kingdom, London: Longmans Green \& Co, 1926. The World's Pilgrim, London: Longmans Green \& Co, 1927.

\section{Pamphlets and booklets}

Women Workers and Parliamentary Representation, Manchester: Lancashire and Cheshire Women Textile and other Workers' Representation Committee, $c 1905$.

Women's Wages and the Franchise and Certain Legislative Proposals, Manchester: Manchester, Salford and District Women's Trade and Labour Council, 1906.

Women's Right to Work, Manchester: William Morris Press, 1906.

Is the Case Urgent? Manchester: National Industrial and Professional Women's Suffrage Society, c 1910.

Whence come Wars? London: Women's Printing Society, 1914. (A speech delivered to the National Industrial and Professional Women's Suffrage Society on 12 December 1914).

Religious Aspects of Non-Resistance, Bishopsgate: Headley Brothers

Printers, 1915. (A paper read at the conference upon the pacifist philosophy of life, Caxton Hall, London, 8 and 9 July 1915).

The Tribunal, London: National Labour Press, $c 1916$.

Rhythms of Art, League of Peace and Freedom Pamphlet, London: The Pelican Press, 1917.

\section{Political articles}

'The Place of Peace,' New Ireland Review, XI, May 1899, p. 176.

'Fair Pay for Women,' The Women's Tribune, 1906.

'Women and Politics: A reply,' Nineteenth Century, March 1907, pp. 472-6.

'The Women's Suffrage Movement among Trade Unionists,' in Brougham Villiers (ed.), The Case for Women's Suffrage, London: 
T. Fisher Unwin, 1907, pp. 50-65.

'Women's Suffrage and the French Revolution,' Academy, 14 September 1907, p. 909.

'Women's Suffrage and the French Revolution,' Academy, 28 September 1907, p. 957.

'Women and the Suffrage: A reply to Lady Lovat and Mrs. Humphry

Ward,' Nineteenth Century and After, September 1908, pp. 495-506. (Reprinted as a pamphlet by the National Industrial and Professional Women's Suffrage Society).

'Women and the Nation: the workers III - "no trades for women," The Englishwoman, 5:2, 1909, pp. 507-17.

'An Equitable Adjustment,' The Common Cause, 30 September 1909, p. 432.

'Running a Suffrage Candidate,' The Common Cause, 25 November 1909, p. 432.

'Women's Wages and the Law of Supply and Demand,' Nineteenth Century and After, August 1914, pp. 384-93.

'Women and Trade Unionism,' Nation, 31 July 1915, p. 573.

'The Sinn Fein Rebellion,' The Socialist Review, August-September 1916, pp. 226-33.

'For God and Kathleen Ni Houlihan,' The Catholic Bulletin, VIII, 1918, pp. 230-4.

\section{Literary contribution to periodicals}

‘To May,' Longman's Magazine, 26:154, Aug 1895, pp. 380-3. 'Fingerposts,' The Yellow Book, X, Jul 1896, pp. 214-17. 'The Place of Peace,' New Ireland Review, X1, May 1899, p. 176. 'Dialogue - Ass and Snake,' Longman's Magazine, 35:205, Nov 1899, pp. 36-9.

'A Heretic's Pilgrimage,' New Ireland Review, 12:4, Dec 1899, p. 214. 'The Queens Flight,' Longman's Magazine, 35:208, Feb 1900, p. 350.

'A Monk's Lament for Maeve,' Longman's Magazine, 38:228, Oct 1901, p. 558.

'Harper's Song of Seasons,' Living Age, 237:320, 2 May 1903.

'Maeve of the Battles,' Longman's Magazine, 42:249, Jul 1903, p. 235.

'Lament for Fionavar,' Longman's Magazine, 43:255, Jan 1904, p. 242.

'Roads of Cloonagh,' Living Age, 242:128, 9 Jul 1904. 
'Reincarnation,' Living Age, 242:448, 13 Aug 1904.

'Maeve of the Battles,' Living Age, 238:704, 12 Sept 1904.

'Nera's Song,' Longman's Magazine, 45:268, Feb 1905, p. 242.

'Beyond,' Dial, 40:330, 16 May 1906.

'Poverty,' Dial, 40:329, 16 May 1906.

'Little Waves of Breffny,' Current Literature, 50:559, May 1911.

'Romance of Maeve,' Literary Digest,' 46:600, 15 Mar 1913.

'Walls,' Literary Digest,' 46:600, 15 Mar 1913.

'Reading given before the Irish Literary Society on Jan 20th by Miss

Eva Gore-Booth,' The Irish Book Lover, VI, Feb 1915, p. 111.

'Little Waves of Breffny,' Literary Digest, 53:420, 19 Aug 1916.

'Little Waves of Breffny,' Country Life, 31:40, Dec 1916.

\section{Contributions to religious and pacifist periodicals}

'The Battle of the Stars,' Occult Review, 24, Aug 1916, p. 83.

'To CA,' Occult Review, 26, Jul 1917, p. 35.

'The Little Girl's Riddle,' Occult Review, 28, Aug 1918, p. 72.

'Consider the Lilies,' Occult Review, 29, May 1919, p. 266.

'The Two Roads,' Herald of the Star, 8, Nov 1919, pp. 514-19.

'The Sense of Something Wrong,' Herald of the Star, 19, Mar 1920, p. 110.

'The Messengers,' The Flame, 1:1, Mar 1920, p. 7.

'The Sense of Something Wrong,' Herald of the Star, 9:3, Mar 1920,

pp. 110-16.

'The Just and the Unjust,' The Venturer, 1:7, Apr 1920, pp. 249-54.

‘The Messengers II,' The Flame, 1:3, May 1920, p. 31.

'Evolution,' The Flame, 1:5, Jul 1920, pp. 53-4.

'The Shepherd of Eternity,' Occult Review, 32, Aug 1920, p. 81.

'Santa Maria Maggiore,' Occult Review, 34, Jul 1921, p. 8.

'A Sketch in Florence,' The Flame, 2:3, Jul-Aug 1921, pp. 37-8.

'The Victim's Friends,' Service, 6:2, Apr 1923, pp. 9-10.

'The Well where the World ends,' Occult Review, 41, Mar 1925,

p. 148.

'Art and Peace,' Service, 4:1, Jan 1926, pp. 8-11.

'The Love that is God in the First Epistle of St. John,' Friends'

Quarterly, Oct 1950, pp. 209-19. 